\title{
Politics, audience costs, and signalling: Britain and the 1863-4 Schleswig-Holstein crisis
}

\author{
Jayme R. Schlesinger and Jack S. Levy* \\ Department of Political Science, Rutgers University, New Brunswick, New Jersey, United States \\ ${ }^{*}$ Corresponding author. Email: jacklevy@polisci.rutgers.edu
}

(Received 21 October 2020; revised 13 March 2021; accepted 14 March 2021; first published online 12 April 2021)

\begin{abstract}
Audience costs theory posits that domestic audiences punish political leaders who make foreign threats but fail to follow through, and that anticipation of audience costs gives more accountable leaders greater leverage in crisis bargaining. We argue, contrary to the theory, that leaders are often unaware of audience costs and their impact on crisis bargaining. We emphasise the role of domestic opposition in undermining a foreign threat, note that opposition can emerge from policy disagreements within the governing party as well as from partisan oppositions, and argue that the resulting costs differ from audience costs. We argue that a leader's experience of audience costs can trigger learning about audience costs dynamics and alter future behaviour. We demonstrate the plausibility of these arguments through a case study of the 1863-4 Schleswig-Holstein crisis. Prime Minister Palmerston's threat against German intervention in the Danish dispute triggered a major domestic debate, which undercut the credibility of the British threat and contributed to both the failure of deterrence and to subsequent British inaction. Parliament formally censured Palmerston, contributing to a learning-driven reorientation in British foreign policy.
\end{abstract}

Keywords: Audience Costs; Signalling; Domestic Political Opposition; Schleswig-Holstein Crisis; Great Britain

\section{Introduction}

The Danish king's declaration of a change in the status of the duchies of Schleswig and Holstein in March 1863, in apparent violation of the terms of the 1852 Treaty of London, triggered British concerns that Prussia and Austria might intervene militarily in the largely German-speaking duchies. In a July 1863 speech to the House of Commons, Prime Minister Viscount Palmerston warned against any external intervention. The prime minister's threat generated substantial domestic debate. After Prussian and Austrian armies marched into Holstein and Schleswig in February 1864, Palmerston did not respond militarily and subsequently withdrew his threat. This precipitated motions for censure in both houses of Parliament in July, narrowly failing in the House of Commons but passing in the House of Lords. Palmerston was subsequently re-elected to Parliament and remained as prime minister until his death in October 1865. His successor, hardline Foreign Secretary Lord John Russell, immediately initiated a much more restrained foreign policy. ${ }^{1}$

\footnotetext{
${ }^{1}$ A. A. W. Ramsay, Idealism and Foreign Policy: A Study of the Relations of Great Britain with Germany and France, 18601878 (London: J. Murray, 1925); Lawrence D. Steefel, The Schleswig-Holstein Question (Cambridge, MA: Harvard University Press, 1932); W. E. Mosse, The European Powers and the German Questions, 1848-71: With Special Reference to England and Russia (Cambridge: Cambridge University Press, 1958); Keith A. P. Sandiford, Great Britain and the Schleswig-Holstein Question: A Study in Diplomacy, Politics, and Public Opinion (Toronto: University of Toronto Press, 1975). In a subsequent section we discuss the First Schleswig-Holstein War (1848-52) and great power crisis associated with it. All references in this study to the 'Schleswig-Holstein crisis' refer to the 1863-4 affair.

(C) The Author(s) 2021. Published by Cambridge University Press on behalf of the British International Studies Association. This is an Open Access article, distributed under the terms of the Creative Commons Attribution licence (http://creativecommons.org/licenses/by/4.0/), which permits unrestricted re-use, distribution, and reproduction in any medium, provided the original work is properly cited.
} 
Given Palmerston's threat, the targets' defiance of the threat, the British failure to follow through, and Parliament's censure of the prime minister, the 1863-4 Schleswig-Holstein crisis appears to fit audience costs theory's basic proposition that domestic publics punish leaders who fail to implement their foreign threats. ${ }^{2}$ Indeed, that was our working hypothesis when we initiated this study, with the aim of exploring the dynamics of punishment by the legislature rather than by the public. Further investigation, however, revealed that Palmerston's failure to implement his threat was the outcome of a complex political process involving opposition from members of Palmerston's own Liberal party in Parliament and from Queen Victoria. Although British behaviour in the Schleswig-Holstein crisis is consistent with some predictions of audience costs theory, on the whole this case constitutes a challenge to audience costs theory. We give particular attention to the various mechanisms through which domestic audiences can undercut their leaders' foreign threats. We argue that scholars need to integrate these mechanisms into a broader theory of the domestic politics of international signalling and interstate bargaining.

The audience costs premise that domestic publics punish leaders for failing to implement their publically-announced external threats generates a number of interconnected hypotheses: (1) Given the importance of costly signalling for bargaining leverage and the greater credibility of public threats than private threats, external adversaries are more likely to comply with public threats than with private threats; (2) the more accountable the leader, the larger the audience costs, the more credible the threat, and the greater leverage in crisis bargaining; (3) audience costs increase as the crisis escalates; (4) the anticipation of domestic punishment discourages leaders from bluffing or from making limited probes with the intention of backing off if they meet resistance; (5) accountable leaders can exploit their bargaining advantages for coercive purposes by deliberately 'going public' with their threats; (6) the primary motivation for punishment is the assumed costs of inconsistency between a leader's words and deeds; and (7) audience costs dynamics can lock states into commitments to escalate over issues for which they would not otherwise be willing to fight. ${ }^{3}$

Critics have pointed to a number of problems with audience costs theory. They argue that: (a) political leaders hesitate to make unambiguous threats that entail a rigid commitment, and prefer more general warnings that maintain their flexibility; (b) publics are more concerned about the substance of policy than with the consistency between a leader's words and deeds; (c) foreign targets do not always understand the implications of audience costs for crisis bargaining; (d) not all domestic costs imposed on leaders derive from audience costs; (e) political leaders' concerns about international reputational costs are often greater than their concerns about domestic audience costs. ${ }^{4}$

British behaviour in the 1863-4 Schleswig-Holstein crisis conforms with some audience costs propositions but not with others, and with some of the critics' arguments but not with others. Contrary to audience costs theory, Palmerston's initial threat was a 'policy of bluff, ${ }^{5}$ made with full confidence that deterrence would work, without assurances of domestic or diplomatic support, and without recognition of potential audience costs or other forms of domestic

\footnotetext{
${ }^{2}$ James D. Fearon, 'Domestic political audiences and the escalation of international disputes', American Political Science Review, 88:3 (1994), pp. 577-92; Kenneth A. Schultz, 'Looking for audience costs', Journal of Conflict Resolution, 45:1 (2001), pp. 32-60. The standard definition of audience costs is 'the domestic price a leader would pay for making foreign threats and then backing down'. Michael Tomz, 'Domestic audience costs international relations: An experimental approach', International Organization, 61:4 (2007), pp. 821-84 (p. 821). Audience costs are separate from the costs of conceding the issues at stake in the dispute.

${ }^{3}$ For additional assumptions underlying audience costs theory propositions, see Branislav L. Slantchev, 'Audience cost theory and its audiences', Security Studies, 21:3 (2012), pp. 376-82.

${ }^{4}$ Jack Snyder and Erica D. Borghard, 'The cost of empty threats: A penny, not a pound', American Political Science Review, 105:3 (2011), pp. 437-56; Marc Trachtenberg, 'Audience costs: an historical analysis', Security Studies, 21:1 (2012), pp. 3-42.

${ }^{5}$ David Cannadine, Victorious Century: the United Kingdom, 1800-1906 (London: Allen Lane, 2017), p. 317; Tudor A. Onea, The Grand Strategies of Great Powers (London: Routledge, 2020), pp. 77, 138.
} 
opposition. The threat was unambiguous, and the Palmerston government continually attempted to reinforce the threat in the coming months. Contrary to the assumption of most audience costs models that nothing intervenes between the initial threat and the adversary's response, domestic elites immediately intervened in opposition to Palmerston's threat, motivated primarily by the belief that the threat was bad policy. Most of the opposition came from within Palmerston's own Liberal party in Parliament and was actively supported by the Queen, who also communicated her views directly and privately to foreign leaders. As predicted by theories of domestic oppositions and signalling, these internal debates undercut the credibility of the threat, both in the eyes of Britain's adversaries and its potential allies. Although the consequences of domestic opposition for signalling and bargaining fit Kenneth Schultz's model, the sources and identity of the opposition in our case do not. ${ }^{6}$ This was intra-party opposition motivated by policy disagreements, not inter-party opposition motivated by partisan politics. ${ }^{7}$

These internal divisions in Britain further reduced the likelihood of external support and contributed to the Prussian and Austrian decisions to defy the threat and intervene militarily in February 1864. Palmerston's inaction and subsequent withdrawal from the crisis led immediately to Parliamentary debates over censure. Subsequently, the public did not punish Palmerston but instead re-elected him, due in part to the prime minister's prior popularity, a variable neglected in audience costs theory. Long-time hawk Lord Russell, who replaced Palmerston after the latter's death, quickly shifted to a non-interventionist foreign policy, beginning with the Austro-Prussian War of 1866. This post-crisis learning about the diplomatic consequences of domestic policy opposition is another variable neglected by audience costs theory.

We develop these themes in this investigation of domestic politics, audience costs, and signalling in Britain in the 1863-4 Schleswig-Holstein crisis. ${ }^{8}$ We pinpoint those aspects of the case that correspond to audience cost mechanisms and predicted outcomes and those that do not. We identify the alternative mechanisms through which domestic politics generated mixed signals and undercut the government's coercive threat. In the process we identify new hypotheses for testing in future research. ${ }^{9}$ Our primary arguments include the following: political leaders are not always initially aware that public threats generate audience costs; other domestic audiences besides the public can play a critical role; in addition to punishing leaders who do not follow through on their threats, these audiences act in ways that dilute the initial threat and reduce its credibility; the extent of punishment is a function of the leader's prior popularity; and leaders

\footnotetext{
${ }^{6}$ Kenneth Schultz, Democracy and Coercive Diplomacy (Princeton, NJ: Princeton University Press, 2001).

${ }^{7}$ On policy disagreements and audience costs, see Snyder and Borghard, 'The cost of empty threats' and Trachtenberg, 'Audience costs'. On the role of political party, see Robert F. Trager and Lynn Vavreck, 'The political costs of crisis bargaining: presidential rhetoric and the role of party', American Journal of Political Science, 55:3 (2011), pp. 526-45.

${ }^{8}$ One can question whether Britain was a democracy at this time. Scholars generally consider Britain a democracy after the Second Reform Act of 1867. The Polity5 Project gives Britain a score of 3 from 1837 to 1867 and classifies it as an 'anocracy', short of a score of 6 for a democracy. Monty G. Marshall and Ted Robert Gurr, 'Polity5: Political Regime Characteristics and Transitions, 1800-2018', Center for Systemic Peace, available at: $\{$ https://www.systemicpeace.org/inscrdata.html $\}$ accessed 9 May 2020. The key question, however, is not whether Britain was democratic but rather whether its leaders were sufficiently accountable to generate audience costs. We will see that British leaders were highly accountable to domestic audiences for their foreign policy decisions, that political opposition was well institutionalised in Britain, and that parliament was the central locus of British politics. On the importance of an institutionalised opposition, see Brandon C. Prins, 'Institutional instability and the credibility of audience costs: Political participation and interstate crisis bargaining, 1816-1992', Journal of Peace Research, 40:1 (2003), pp. 67-84. It is also clear that British leaders were more sensitive to audience costs than were leaders of its Prussian and Austrian adversaries. This is important given the argument that 'the state more sensitive to audience costs is always less likely to back down in disputes that become public contests'. Fearon, 'Domestic political audiences', p. 577.

${ }^{9}$ This is best categorised as a hypothesis-generating case study. On typologies of case studies, see John Gerring, 'Qualitative methods', Annual Review of Political Science, 20 (2017), pp. 15-36; Jack S. Levy, 'Case studies: Types, designs, and logics of inference', Conflict Management and Peace Science, 25:1 (2008), pp. 1-18 (pp. 5-6). On the utility of historical case studies for assessing both the existence of audience costs and their perceptions by politicians, given limitations of both large- $\mathrm{N}$ statistical approaches and experimental approaches, see Schultz, 'Looking for audience costs', p. 53.
} 
draw lessons from audience costs and from policy failures driven by domestic opposition, and they adjust their policies accordingly. We emphasise that neither the leader's threat, the adversary's response, nor audiences' responses are discrete events but instead evolve and interact over time. We conclude that audience costs are inseparable from politics and should be subsumed within a more general theory of domestic politics and signalling.

\section{Audience costs: Theoretical issues}

The idea that publically announced external threats have domestic political implications that influence relations with adversaries is familiar. ${ }^{10}$ More systematic study of these phenomena did not begin, however, until James D. Fearon constructed a formal model of audience costs, Kenneth Schultz highlighted the methodological problems of strategic selection, and Michael Tomz demonstrated the potential utility of survey experiments for testing audience costs theory. ${ }^{11}$ The study of audience costs continues to be one of the most visible research programmes in the International Relations field.

The domestic costs a leader may suffer from making a foreign threat but failing to follow through include disapproval of the leader's handling of the crisis, a decline in their general approval ratings, removal from office, reduced influence with the legislature, increased domestic opposition to policy initiatives, stalled policy agendas, and, in some authoritarian regimes, personal costs. ${ }^{12}$ Not all domestic costs associated with issuing external threats are audience costs. The emergence of domestic opposition to the implementation of the threat prior to any defiance of the threat does not qualify as audience costs. ${ }^{13}$ Joshua D. Kertzer and Ryan Brutger ${ }^{14}$ usefully distinguish between 'inconsistency costs' arising from the discrepancy between a leader's threats and their actions, and 'belligerence cost' associated with making an unpopular initial threat. ${ }^{15}$

Political leaders worry about potential international reputational costs of their actions independently of their domestic costs. This raises some difficult conceptual and methodological issues. Given evidence that reputational concerns prompt a leader to stand firm after making a threat, how do we know whether those concerns are motivated by audience costs as opposed to the state's reputational costs? The problem is complicated by the fact that international reputational costs and domestic audience costs are causally related. Fearon argues that backing down after making a show of force ... gives domestic political opponents an opportunity to deplore the international loss of credibility, face, or honor'. ${ }^{16}$ Tomz argues that citizens' concerns about the country's (or the leader's) international reputation is the primary source of audience costs. ${ }^{17}$ In Tomz's open-ended survey of why respondents punish their leaders for making a

\footnotetext{
${ }^{10}$ Thomas C. Schelling, Strategy of Conflict (Cambridge, MA: Harvard University Press, 1960); Robert Jervis, The Logic of Images in International Relations (Princeton, NJ: Princeton University Press, 1970).

${ }^{11}$ Fearon, 'Domestic political audiences'; Schultz 'Looking for audience costs'; Tomz, 'Domestic audience costs'.

${ }^{12}$ Tomz, 'Domestic audience costs', pp. 831-3; H. E. Goemans, 'Which way out? The manner and consequences of losing office', Journal of Conflict Resolution, 52:6 (2008), pp. 771-94; Christopher Gelpi and Joseph M. Grieco, 'Competency costs in foreign affairs: Presidential performance in international conflicts and domestic legislative success, 1953-2001', American Journal of Political Science, 59:2 (2015), pp. 440-56.

${ }^{13}$ Snyder and Borghard, 'The cost of empty threats'; Trachtenberg, 'Audience costs'; Stephen Chaudoin, 'Promises or policies? An experimental analysis of international agreements and audience reactions', International Organization, 68:1 (2014), pp. 235-56.

${ }^{14}$ Joshua D. Kertzer and Ryan Brutger, 'Decomposing audience costs: Bringing the audience back into audience cost theory', American Journal of Political Science, 60:1 (2016), pp. 234-49.

${ }^{15}$ On balancing the two costs, see Matthew Hauenstein, 'The conditional effect of audiences of credibility', Journal of Peace Research, 57:3 (2020), pp. 422-36. For a critique of this conceptualisation, see William G. Nomikos and Nicholas Sambanis, 'What is the mechanism underlying audience costs? Incompetence, belligerence, and inconsistency', Journal of Peace Research, 56:4 (2019), pp. 575-88.

${ }^{16}$ Fearon, 'Domestic political audiences', p. 581.

${ }^{17}$ Tomz, 'Domestic audience costs'. Although domestic audience costs and international reputational costs are difficult to tease apart, Fearon claims that leaders worry more about domestic audience costs than about external reputational costs,
} 
threat and failing to follow through, the vast majority (72 per cent) emphasised the costs to the country's reputation and credibility. ${ }^{18}$

Audience costs, and hence the credibility of threats, increase with the accountability of the leader, which varies across types of political systems. Following Fearon, most scholars assume that democratic leaders face greater audience costs than do authoritarian leaders. Recent research has demonstrated, however, that audience costs in authoritarian states can sometimes be substantial. ${ }^{19}$ Accountability and audience costs also vary across democracies and their varying degrees of press freedoms and public access to the media. A reliably informed public is necessary for public awareness of the external environment, their leader's threats, the reaction of external (and internal) actors, and the leader's response. ${ }^{20}$ The media can also mitigate audience costs by presenting new information or changing circumstances (or leaders' claims of such) that appear to justify decisions not to implement a threat. ${ }^{21}$

One factor that might detract from the credibility of public threats is the presence of multiple domestic audiences with different attitudes towards both the initial threat and the costs and benefits of following through or not. Fearon identifies numerous domestic audiences, including 'kings, rival ministers, opposition politicians, Senate committees, politburos, and, since the midnineteenth century, mass publics informed by mass media in many cases'. These audiences punish leaders in different ways, but Fearon and subsequent empirical and experimental studies of democracies focus exclusively on domestic publics. ${ }^{22}$

The existence of multiple audiences raises a number of additional questions worth theoretical and empirical exploration. What happens when some audiences back the government's policy while others oppose it? To what audiences does the government give most attention? At what stage of an international crisis do various audiences express their opinions - prior to the initiation of the threat, between the initiation of the threat and the adversary's response, or after the adversary's response and the government's failure to implement its initial threat?

because, he argues, a leader's hold onto power is shaped more by domestic developments than by international ones. See Fearon, 'Domestic political audiences', p. 581.

${ }^{18}$ Tomz, 'Domestic audience costs'. Some respondents suggested that saying one thing and doing another reflects incompetence, while others expressed ethical concerns. For more on perceptions of incompetence, see Alastair Smith, 'International crisis and domestic politics', American Political Science Review, 92:3 (1998), pp. 623-38; Gelpi and Grieco, 'Competency costs'; and Nomikos and Sambanis, 'What is the mechanism?'. Central to each of these arguments is inconsistency. This inconsistency argument is reinforced by evidence that publics also punish leaders (but to a lesser extent) for saying that they will stay out of a foreign crisis but then 'back in' and intervene in the crisis. Jack S. Levy, Michael K. McKoy, Paul Poast, and Geoffrey P. R. Wallace, 'Backing out or backing in? Commitment and consistency in audience costs theory', American Journal of Political Science, 59:4 (2015), pp. 988-1001.

${ }^{19}$ Fearon, 'Domestic political audiences'; Jessica L. Weeks, 'Autocratic audience costs: Regime type and signaling resolve', International Organization, 62:1 (2008), pp. 35-64; Jonathan N. Brown and Anthony S. Marcum, 'Avoiding audience costs: Domestic political accountability and concessions in crisis diplomacy', Security Studies, 20:2 (2011), pp. 141-70; Jessica Chen Weiss, 'Authoritarian signaling, mass audiences, and nationalist protest in China', International Organization, 67:1 (2013), pp. 1-35. It is important to note that democracies' superior signalling ability based on a greater capacity to generate audience costs is a plausible proposition but not a logical consequence of audience costs theory. Consequently, evidence against the democratic advantage proposition would not by itself disconfirm audience costs theory. Jack S. Levy, 'Coercive threats, audience costs, and case studies', Security Studies, 21:3 (2012), pp. 383-90 (p. 385); Slantchev, 'Audience cost theory', p. 378.

${ }^{20}$ Branislav L. Slantchev, 'Politicians, the media, and domestic audience costs', International Studies Quarterly, 50:2 (2006), pp. 445-77; Philip B. K. Potter and Matthew A. Baum, 'Looking for audience costs in all the wrong places: Electoral institutions, media access and dispute reciprocation', Journal of Politics, 76:1 (2014), pp. 167-81.

${ }^{21}$ Matthew S. Levendusky and Michael C. Horowitz, 'When backing down is the right decision: Partisanship, new information, and audience costs', Journal of Politics, 74:2 (2007), pp. 323-38.

${ }^{22}$ Fearon, 'Domestic political audiences', p. 581; Tomz, 'Domestic audience costs'; Levendusky and Horowitz, 'When backing down is the right decision'; Slantchev, 'Audience cost theory'; Gelpi and Grieco, 'Competency costs'; Kertzer and Brutger, 'Decomposing audience costs'; Graeme A. M. Davies and Robert Johns, 'Audience costs among the British public: The impact of escalation, crisis type, and prime ministerial rhetoric', International Studies Quarterly, 57:4 (2013), pp. 725-37. Levendusky and Horowitz include the reaction of other elites in their experimental studies, but their focus is still on the response of the public and its consequences. Levendusky and Horowitz, 'When backing down is the right decision'. 
Another question on which audience costs theorists are silent is whether political leaders learn after experiencing audience costs. After making a threat, backing down, and incurring domestic punishment, are leaders more hesitant in the future to make threats they might not be willing or able to implement ${ }^{23}$ Or, might they be even more determined to make an external threat and implement that threat if challenged, to restore their reputation? Do external adversaries anticipate one of these reactions and adjust their bargaining strategies accordingly? We interpret the rationalist micro-foundations of audience costs theory to imply that actors understand audience costs dynamics and consequently are not surprised by them, leaving nothing to learn, at least not about the causal dynamics of audience costs. ${ }^{24}$ We demonstrate that British leaders learned from their policy failure in the Schleswig-Holstein crisis and from the ensuing censure debate and significantly changed their policies as a result.

This discussion of learning about audience costs raises the prior question of whether leaders, when they make external threats, are aware that they are generating the potential for audience costs, with their important consequences for crisis bargaining. When audience costs theorists say, as they often do, that leaders 'generate' or 'create' audience costs, they generally assume the leader intentionally makes a public threat rather than a private threat to create audience costs and thereby enhance their bargaining advantages. Fearon describes this as a 'tying hands strategy of signaling resolve, with international crises becoming competitions in creating domestic political audience costs'. ${ }^{25}$ Marc Trachtenberg talks about leaders 'going public' and 'stirring up opinion at home to strengthen their bargaining position'. ${ }^{26}$

Although it may be true that leaders who make external threats usually understand audience costs and that they often make their threats public for that reason, there is nothing in Tomz's widely repeated definition of audience costs about a leader's intentions in making a threat or awareness of its possible consequences. ${ }^{27}$ A leader's awareness is a theoretical prediction. The definition is strictly behavioural. Whether the initiators and targets of threats understand their domestic effects and their implications for crisis bargaining are empirical questions. A leader's lack of awareness of the domestic implications of an external threat would raise questions about the validity of many audience costs theory propositions, including the basic argument that public threats enhance the bargaining leverage of the more accountable leader. We find no evidence in the Schleswig-Holstein case that Palmerston was aware that he was generating audience costs when he announced his deterrent threat in the House of Commons, or that he even considered the possibility of a domestic reaction when he made the threat. We suspect this is not an isolated case. ${ }^{28}$

\footnotetext{
${ }^{23}$ On learning from history, and in particular from the last major policy failure, see Robert Jervis, Perception and Misperception in International Politics (Princeton, NJ: Princeton University Press, 1976), ch. 6; Jack S. Levy, 'Learning and foreign policy: Sweeping a conceptual minefield', International Organization, 48:2 (1994), pp. 279-312 (pp. 304-06).

${ }^{24}$ Audience costs theory emphasises learning within a crisis about the other side's resolve by observing its ability to generate audience costs. Fearon, 'Domestic political audiences'. We examine post-crisis causal learning about audience costs dynamics. On the distinction between causal learning and diagnostic learning (about preferences, intentions, resolve, or capabilities), see Levy, 'Learning and foreign policy', pp. 285-6.

${ }^{25}$ James D. Fearon, 'Signaling foreign policy interests: Tying hands versus sinking costs', Journal of Conflict Resolution, 41:1 (1997), pp. 68-90 (p. 68).

${ }^{26}$ Trachtenberg, 'Audience costs', p. 11.

${ }^{27}$ Tomz, 'Domestic audience costs', p. 821.

${ }^{28}$ Consider Barack Obama's 'red line' threat. When Obama responded to a reporter's question on 12 August 2012 at a press conference by warning Syrian President Bashar Hafez al-Assad against using or moving chemical weapons, he was not making a planned policy statement and probably did not realise that he was generating audience costs. Obama's advisors, probably motivated by human rights concerns, initially made a series of statements reinforcing the threat. In early December, after media reports of movements of Syrian chemical weapons in violation of Obama's threat, Obama responded with a more ambiguous warning about an American response. He eliminated the 'red line' language from his earlier statement, presumably with the aim of minimising reputational and/or audience costs. For more on Obama's 'red line' threat, see Erica D. Borghard and Jack Snyder, 'Evading invasion: Syria's chemical weapons and Obama's audience costs', Political
} 
This discussion of the extent of a leader's awareness of potential audience costs raises questions about the leader's other calculations when making a foreign threat. Fearon notes that a central feature of his model is that 'neither the balance of forces nor the balance of interests has any direct effect on the probability that one side rather than the other will back down once both sides have escalated'. He explains that when they consider whether to initiate a threat or resist an adversary's threat, rational leaders 'take into account observable indices of relative power and interest in a way that tends to neutralize their impact if a crisis ensues'. Consequently, 'which side backs down in a crisis should be determined by relative audience costs and by unobservable, privately known elements of state capabilities and resolve'. ${ }^{29}$ This is a theoretically plausible argument, but we need to know whether it is empirically valid as well as theoretically useful. We demonstrate that Palmerston did not take observable elements of relative power into account when he initiated his threat, but that Queen Victoria and Liberal members of Parliament did, and that observable indicators of the lack of British diplomatic support were the core of their opposition to Palmerston's coercive policies.

If a leader makes a threat and only later realises its domestic implications, the leader and/or their advisors may try to 'walk back' the threat. ${ }^{30}$ Alternatively, the government may try to reinforce the threat through subsequent statements and actions. These possibilities do not fit neatly into formal audience costs models and experimental protocols, in which a leader either makes or does not make a threat. Moreover, a threat (public or otherwise) often does not lead to an immediate decision by the adversary whether or not to respond. There is further signalling and bargaining, actions by third parties - internal as well as external - that change the actors' incentives and domestic constraints. In our case, Britain pursued a dual strategy of threat and conflict management for six months, accompanied by internal debate and interrupted by another provocative move by the Danish king, before Prussia crossed Britain's red line with military action in Schleswig.

Standard audience costs theory makes other assumptions about dichotomous choices that have been theoretically useful in advancing the audience costs research programme but that can be relaxed in future studies, certainly in applications to individual cases. Standard models assume that the adversary either complies with the threat or not, but adversaries can devise alternative responses and 'design around' a deterrent threat with more nuanced strategies. ${ }^{31}$ Conventional models assume that the threatening state either follows through or not, but the leader can respond but in a more limited way, 'backing up' rather than backing down, mitigating audience costs. ${ }^{32}$ Future research should explore the implications of these alternative strategies. Punishment can also vary in magnitude, in kind, and by source. Our study of Britain in the Schleswig-Holstein crisis explores some of these questions.

\section{Britain and the 1863-4 Schleswig-Holstein crisis}

We begin with the historical background, beginning with a brief summary of the 1848-50 Schleswig-Holstein crisis, which sets the stage for the subsequent crisis. We examine the changing diplomatic circumstances leading up to the 1863-4 crisis, the Danish actions that triggered it, Palmerston's public threat to deter German intervention, and the ensuing interstate bargaining and complex political maneuvering within Britain. We then explore the escalation of the crisis in February 1864, Britain's withdrawal from the dispute in June, censure by Parliament in July, and the subsequent reorientation of British foreign policy.

\footnotetext{
Violence at a Glance (2012), available at: \{https://politicalviolenceataglance.org/2012/12/13/evading-invasion-syrias-chemicalweapons-and-obamas-audience-costs/ $\}$ accessed 27 February 2020.

${ }^{29}$ Fearon, 'Domestic political audiences', p. 578.

${ }^{30}$ For more on strategies for 'decoupling' from a threat, see Jervis, Logic of Images, ch. 7.

${ }^{31}$ Alexander L. George and Richard Smoke, Deterrence in American Foreign Policy: Theory and Practice (New York: Columbia University Press, 1974).

${ }^{32}$ Erik Lin-Greenberg, 'Backing up, not backing down: Mitigating audience costs through policy substitution', Journal of Peace Research, 56:4 (2019), pp. 559-74.
} 


\section{Historical background}

The Schleswig-Holstein issue concerned the political fate of the duchies of Schleswig, Holstein, and, secondarily, Saxe-Lauenburg. Each had historic ties to the Danish crown through personal unions, but they had different political arrangements. Holstein, nearly exclusively Germanspeaking, belonged to the German Confederation. Schleswig was predominantly Danish in the north and German in the south. In the context of rising nationalism in Europe and increased tensions between Danes and Germans in Schleswig, King Frederick VII formally incorporated Schleswig into Denmark in 1848, precipitating a rebellion by German-speaking majorities in Schleswig and Holstein. After Danish troops intervened, Prussia followed, occupied the duchies, and invaded Denmark. Britain, under Prime Minister John Russell and Foreign Minister Palmerston, and Russia, under Nicholas I, worried about possible German control of the strategic port of Kiel and of the Baltic. Backed by diplomatic support from France, Russia threatened to intervene against Prussia. After several armistices, a July 1850 peace settlement was formalised in the Treaty of London on 2 May $1852 .{ }^{33}$ The treaty restored the Danish king's authority in Holstein, but only under the conditions that the Danish king promise not to incorporate Schleswig into Denmark or to make any constitutional reforms in the duchies without first consulting Prussia and Austria. The treaty also dealt with a complicated succession question by specifying that Frederick's successor would not become the new Duke of Holstein or of Lauenburg. ${ }^{34}$

The international environment shifted significantly in the ten years before the 1863-4 Schleswig-Holstein crisis. The 1853-6 Crimean War and then the 1863 Polish crisis alienated Russia from the Western powers, removing the Russian threat that had played a critical role in the settlement of the earlier crisis. ${ }^{35}$ Britain's failure to follow up its tough talk in the Polish crisis also angered France and raised concerns about British credibility. Napoleon III's revisionist ambitions - made all the more transparent by his public statement that the 1815 Vienna settlement was 'outmoded' - further alienated Britain from France and led Palmerston to fear France as much he did Prussia. ${ }^{36}$ These developments fractured the coalition that had successfully resolved the 1848-50 crisis and created opportunities for Prussian expansion under Bismarck. ${ }^{37}$ In each crisis, Britain was led by Russell and Palmerston, with their formal governmental positions reversed. This suggests the possibility that the successful use of coercion in 1848-50 contributed to the adoption of same strategy in the 1863-4 crisis, consistent with hypotheses that leaders learn from the last major crisis but often neglect the importance of context here, the changed diplomatic environment.

\section{The initiation of the crisis}

Frederick VII's 30 March 1863 declaration of the 'March Patent', which formally separated the duchies of Holstein and Saxe-Lauenburg from Denmark, triggered the 1863-4 Schleswig-Holstein crisis. It violated the terms of the Treaty of London, generated fears that the king might try to formally

\footnotetext{
${ }^{33}$ Steefel, Schleswig-Holstein Question, pp. 3-13, 265-7; Sandiford, Great Britain and the Schleswig-Holstein Question, pp. $20-7$.

${ }^{34}$ Holger Hjelholt, Great Britain, the Danish-German Conflict, and the Danish Succession, 1850-1852: From the London Protocol to the Treaty of London (the $2^{\text {nd }}$ of August 1850 and the $8^{\text {th }}$ of May 1852) (Denmark: Bianco Lunos Bogtrykkri A/S, 1971), p. 250; William E. Mosse, 'Queen Victoria and her ministers in the Schleswig-Holstein crisis, 1863-1864', English Historical Review, 78:307 (1963), pp. 263-83 (p. 263).

${ }^{35}$ After France supported the Polish rebels while Prussia's new Minister of Foreign Affairs Otto von Bismarck supported Russia, Tsar Alexander II saw France as a greater threat than Prussia.

${ }^{36}$ Mosse, European Powers, p. 177; Paul M. Kennedy, The Rise of the Anglo-German Antagonism, 1860-1914 (London: George Allen \& Unwin, Ltd, 1980), p. 12. Palmerston was also concerned about the possible impact of the American Civil War on British interests in North America. David Brown, Palmerston (New Haven, CT: Yale University Press, 2010), pp. 450-5.

${ }^{37}$ René Albrecht- Carrié, A Diplomatic History of Europe Since the Congress of Vienna (New York: Harper \& Row, 1958), chs III-IV; Mosse, European Powers, ch. 5.
} 
incorporate Schleswig into Denmark. This outraged German Confederation states. In early July the German Federal Diet demanded that Frederick VII withdraw the Patent within six weeks. Sweden supported Denmark and urged Britain and France to follow. Britain, along with Sweden, made no commitment and tried to dissuade Denmark from further provoking the German states. ${ }^{38}$

In a 23 July 1863 meeting of the House of Commons, Prime Minister Palmerston was asked 'what course Her Majesty's Government were prepared to pursue if the Germanic Confederation should attempt to occupy Holstein, and that occupation should be resisted by a Danish force'. Palmerston emphasised the importance of 'the independence, the integrity, and the rights of Denmark'. He warned that 'if any violent attempt were made to overthrow those rights and interfere with that independence, those who made the attempt would find in the result, that it would not be Denmark alone with which they would have to contend'. ${ }^{39}$ The following day the newspapers published the initial threat, along with the government's announced intentions to secure a diplomatic settlement. ${ }^{40}$

Palmerston and Russell worried that the Danish action and a German response would undercut a stable European order by facilitating Prussian expansion and, secondarily, by violating the sanctity of treaties. They were particularly concerned about the potential for German control in the Baltic Sea. ${ }^{41}$ Most historians argue that neither Palmerston nor Russell wanted war but believed that coercive threats would be sufficient to deter the German states, and Prussia in particular, from aggressive action toward Denmark. Palmerston and Russell were confident, however, that Britain was prepared to act should the need arise. ${ }^{42}$ They also believed, correctly, that there was significant sympathy for the Danish monarchy in the Cabinet and British public, and, incorrectly, that this would reinforce deterrence. ${ }^{43}$ They adopted a dual strategy of reinforcing the threat while simultaneously pursuing a diplomatic solution in hopes of avoiding a war. In late August Russell warned Prussia and Austria that they would be 'responsible for the consequences' if they undertook military action. ${ }^{44}$

With audience costs theory predicting that leaders are careful to ensure domestic support for policies - to maximise their bargaining leverage with adversaries, it is puzzling that Palmerston made no effort to secure support from his Cabinet or from potential foreign allies before issuing his threat - especially at a time when the constellation of political forces in the Cabinet and Parliament opposed an interventionist policy. Although the Cabinet, the Queen, the media, and the informed public generally agreed with Palmerston and Russell that British interests required an independent Danish state, they recognised Britain's international isolation and feared a war without allies. The Queen actively opposed Palmerston's policies of deterrence. Although they agreed on abstract principles, Conservatives were divided on the proper policy response.

\footnotetext{
${ }^{38}$ Ramsay, Idealism and Foreign Policy, pp. 113-19; Steefel, Schleswig-Holstein Question, pp. 55-82; Mosse, European Powers, p. 152; E. L. Woodward, The Age of Reform, 1815-1870 (Oxford: Clarendon Press, 1938), p. 307.

${ }^{39}$ Great Britain, House of Commons, Debates (1863-07) vol. 172, cols 1246-1252 (hereafter HC Deb).

${ }^{40}$ 'House of Commons', The Times of London (24 July 1863), pp. 6-8. The media was generally neutral in its coverage, but The Morning Post or the Daily Telegraph supported Palmerston. For more on Palmerston and the media, see Jasper Godwin Ridley, Lord Palmerston (London: Constable, 1970), pp. 524-6.

${ }^{41}$ Sandiford, Great Britain and the Schleswig-Holstein Question, p. 32.

${ }^{42}$ Mosse, European Powers, p. 150; Sandiford, Great Britain and the Schleswig-Holstein Question, p. 89; Paul Scherer, Lord John Russell: A Biography (London: Associated University Presses, 1999), pp. 303-05; F. R. Bridge and Roger Bullen, The Great Powers and the European States System, 1814-1914 (New York: Person Educated Limited, 2005 ), p. 152. Palmerston's bluff deviated from his past practice and from a norm dating back to an 1823 statement of British leader (and Palmerston's political mentor) George Canning: 'a menace not intended to be executed is an engine which Great Britain could never condescend to employ'. See Onea, Grand Strategies, p. 133. We attribute Palmerston's shift in part to learning from success in the 1848-50 crisis.

${ }^{43}$ Sandiford, Great Britain and the Schleswig-Holstein Question, p. 57; Laurence Fenton, Palmerston and the Times: Foreign Policy, the Press, and Public Opinion in Mid-Victorian Britain (London: I. B. Tauris, 2012), p. 158.

${ }^{44}$ Scherer, Lord John Russell, p. 303.
} 
Business groups, particularly in the north, opposed military action, as did most of the Liberal Cabinet. ${ }^{45}$

When Frederick VII died without direct descendants in November 1863, Christian (IX) of Glücksburg claimed the title of King of Denmark and Duke of Schleswig-Holstein and Saxe-Lauenburg. He signed the recently passed November Constitution, formally integrating Schleswig into Denmark. German states protested, claiming that this violated the Treaty of London and the rules of succession in the duchies. Frederick of Augustenburg claimed the title of Duke of Schleswig-Holstein, immediately winning the support of the German Diet and the nationalist movement. Bismarck, thinking a few moves ahead, opposed, fearing the possible creation of an independent north German state in Augustenburg that would block the expansion of Prussian influence into north Germany. He also believed that emphasising the sanctity of treaties and the Treaty of London had a better chance of minimising the likelihood of a wider war. ${ }^{46}$

Britain urged Denmark to withdraw the November Constitution and to make further concessions. Denmark stood firm and unsuccessfully appealed to Britain for military aid. After Saxon and Hanoverian troops occupied Holstein and Lauenburg on 24 December, forcing Denmark to concede those provinces to the German Confederation, the British government returned to a more aggressive policy of deterrence, confident that they could manage the crisis and avoid escalation to an Anglo-German war. ${ }^{47}$ But British policy was inconsistent. In early January 1864 Palmerston assured the Queen and the opposition in the Cabinet, that 'there was no question whatever of England going to war'. Shortly after, Russell warned the Prussian envoy that Britain 'could not consistently with honour allow Denmark to perish without aiding her in her defence. ${ }^{48}$

The Palmerston government's dual strategy of reinforcing the threat while searching for a negotiated solution with Prussia while pressuring Denmark sent mixed messages. The behaviour of internal actors, particularly the Cabinet and Queen Victoria, played an even greater role in undermining the credibility of Palmerston's threat. ${ }^{49}$ The Queen's underlying sympathies lay with the Germans, which was well known in foreign capitols and affected their calculations and bargaining strategies. ${ }^{50}$ She questioned whether British interests in Schleswig-Holstein warranted a war, particularly in the absence of French support. ${ }^{51}$ Leveraging her personal relationships with other royals throughout Europe, the Queen also communicated directly with foreign adversaries and allies, undercutting uncompromising messages from Palmerston and Russell. ${ }^{52}$

\footnotetext{
${ }^{45}$ Kennedy, Rise of Anglo-German Antagonism, p. 12.

${ }^{46}$ Steefel, Schleswig-Holstein Question, pp. 71-5; Woodward, Age of Reform, pp. 307-08; Mosse, European Powers, p. 154; Bridge and Bullen, Great Powers, pp. 98-9; Stacie E. Goddard, 'When right makes might: How Prussia overturned the European balance of power', International Security, 33:3 (2008/09), pp. 110-42.

${ }^{47}$ Sandiford, Great Britain and the Schleswig-Holstein Question, p. 76.

${ }^{48}$ Mosse, European Powers, pp. 161-2.

${ }^{49}$ The Queen had no formal authority in the policy making process, and the British government had no constitutional obligation to consider her views, but Victoria's position as Queen gave her great prestige and the basis for influence, and prime ministers needed to engage her skillfully. On the role of the Queen, see Frank Hardie, The Political Influence of Queen Victoria, 1861-1901 (London: Frank Cass, 1963).

${ }^{50}$ Mosse, 'Queen Victoria', p. 282; Hardie, Political Influence, p. 147; George Earle Buckle, The Letters of Queen Victoria, Second Series: A Selection from Her Majesty's Correspondence and Journal Between the Years 1862 and 1878 (New York: Longmans \& Co., 1928), pp. 135, 158. The fact that the Queen was one of the few to advocate British (and French) intervention against Prussian expansion in 1866 suggests caution in attributing too much weight to her German sympathies in the Schleswig-Holstein crisis.

${ }^{51}$ Otto Pflanze, Bismarck and the Development of Germany, Vol. I: the Period of Unification, 1815-1871 (Princeton: Princeton University Press, 1990), p. 248.

${ }^{52}$ Sandiford, Great Britain and the Schleswig-Holstein Question, pp. 93-5, 147-8; Goddard, 'When right makes might', p. 132; James W. Davis, Threats and Promises: the Pursuit of International Influence (Baltimore, MD: Johns Hopkins University Press, 2003), pp. 61-2; Eric Eyck, Bismarck and the German Empire (London: George Allen \& Unwin, Ltd, 1950), p. 92. For the letters, see Buckle, Letters. For the history of political clashes between Queen Victoria and Palmerston, see Brown, Palmerston.
} 
Queen Victoria also pushed the Cabinet, the majority of which was sceptical of war, to moderate the substance and tone of the government's warnings to Prussia and Austria. ${ }^{53}$ She often exerted her domestic influence through Lord Granville, the leader of the 'pacific' majority in the Cabinet. ${ }^{54}$ Members were aware of the close connection, increasing Granville's influence. In effect, the Queen 'had her own party in the Cabinet'. ${ }^{55}$ On numerous occasions, Russell submitted to the Queen for her approval draft warnings to Prussia or notifications to other states of Britain's intent to use military force if necessary. The Queen often responded by criticising the tone of the dispatches and insisting that the language first be reviewed by Cabinet, which then rejected Russell's drafts. ${ }^{56}$ In early January 1864, when Palmerston warned the Prussian ambassador to London of Britain's intentions to intervene, the Queen informed Palmerston that she would oppose war over the Schleswig-Holstein issue. Days later Granville confronted Palmerston about 'plunging [Britain] into a war for the maintenance of the Treaty of 1852 '. ${ }^{57}$

In late January, when Palmerston attempted to send a squadron of the British fleet to Copenhagen in response to the presence of Austrian forces in the English Channel, the Queen's allies in the Cabinet immediately vetoed this decision and recalled the fleet back to Britain. ${ }^{58}$ After the Prussian invasion of Schleswig, Victoria urged that the 'more dignified course for England will be to remain passive. ${ }^{59}$ Nevertheless, British ambassadors to the German states continued to believe that an unambiguous British threat would deter military action against Denmark and urged the British government to stand firm. ${ }^{60}$ The British ambassador to Berlin noted that 'the King and all Germany should understand clearly that Great Britain is prepared, in certain eventualities, to give material aid to Denmark' ${ }^{61}$

Bismarck understood the hollowness of these threats. He had been cautious in his foreign policy toward Denmark, ${ }^{62}$ recognising the risks but confident that he could manage those risks as long as Britain remained isolated and internally divided. ${ }^{63} \mathrm{He}$ had been careful to do everything possible to maintain that isolation and reinforce its domestic divisions. ${ }^{64}$ Bismarck did this through his actions and his rhetoric, including, for example, his emphasis on maintaining the sanctity of the Treaty of London.

Lord Ellenborough argued in Parliament in May 1864 that it was the Queen's influence that undermined the credibility of Palmerston's threat. ${ }^{65}$ Palmerston reached the same conclusion. In May 1864 he wrote that '[The Germans] have been encouraged hitherto by a belief that nothing

\footnotetext{
${ }^{53}$ Raymond James Sontag, Germany and England: Background of Conflict, 1848-1894 (New York: Russell \& Russell, Inc., 1964), p. 81; Warren B. Morris Jr, 'The Danish-German war of 1865 and British politics', Proceedings of the Oklahoma Academy of Sciences Open Journal, 51 (1971), pp. 131-5 (p. 134). Britain's internal divisions were exacerbated by increasing demands for reform from the middle class and trade unionists, and the increasing influence of arguments by Cobden and Manchester liberals that Britain would be best served by peace that supported free trade. Kennedy, Rise of Anglo-German Antagonism, p. 11.

${ }^{54}$ Mosse, European Powers, p. 161.

${ }^{55}$ Ramsay, Idealism and Foreign Policy, p. 103.

${ }^{56}$ Mosse, European Powers, pp. 157, 162; Sandiford, Great Britain and the Schleswig-Holstein Question, pp. 86, 90.

${ }^{57}$ Mosse, European Powers, p. 161.

${ }^{58}$ Steefel, Schleswig-Holstein Question, pp. 177-8; Morris, 'The Danish-German war', p. 134.

${ }^{59}$ Buckle, Letters, p. 155. The Palmerston government's signals of strength were also undermined by Chancellor of the Exchequer William Gladstone's insistence on balance budgets, including the reduced military spending in the government's proposed 1864 budget. Brown, Palmerston, pp. 459-65; Kennedy, Rise of Anglo-German Antagonism, p. 12.

${ }^{60}$ Mosse, European Powers, p. 162; Sandiford, Great Britain and the Schleswig-Holstein Question, p. 89.

${ }^{61}$ Mosse, European Powers, p. 175.

${ }^{62}$ Davis, Threats and Promises, pp. 54-60.

${ }^{63}$ Eyck, Bismarck, p. 85; Mosse, European Powers, p. 150.

${ }^{64}$ Bismarck commented that 'The Schleswig-Holstein question was a nut on which we might well have broken our teeth ... [I]t was only a question of creating a favorable situation ... England had to be isolated so that she would confine herself to threats, as she always does when no one will pull the chestnuts out of the fire for her.' Steefel, Schleswig-Holstein Question, pp. $94-5$.

${ }^{65}$ Sandiford, Great Britain and the Schleswig-Holstein Question, p. 130.
} 
would induce us [Britain] to interfere; and this belief has been much strengthened, unfortunately, by letters and language received in [Britain]. ${ }^{66}$ Thus Palmerston finally recognised that his initial threat and subsequent policies had generated domestic opposition that reduced the effectiveness of his policies. To the extent that this is a form of punishment, note that this behaviour does not fit audience costs theory. It was motivated primarily by disagreements with the substance of Palmerston's policies, and it began long before the Austro-Prussian defiance of his threat.

\section{The German invasion and the British response}

With the November Constitution providing Bismarck with his 'favorable situation', on 16 January 1864 Prussia and Austria jointly issued an ultimatum to Denmark to revoke the new constitution within 48 hours. When Denmark failed to respond, Prussian and Austrian troops entered Holstein and Lauenburg. On 1 February they crossed into Schleswig, formally beginning the Second Schleswig-Holstein interstate war. Palmerston took no action. He did not provide Denmark with the military aid he had promised. He told Parliament on 9 February that concessions would be unlikely to induce the German states to retreat and that he had received 'no guarantee from Austria and Prussia that they will evacuate Schleswig when the constitution is revoked'. ${ }^{67}$ Prussia and Austria rejected a 10 February British proposal for an armistice if Denmark completely evacuated Schleswig and continued their advance while Denmark appealed for support.

Palmerston was well aware (as was Bismarck) that Britain was not in a position to respond by itself, given its limited capabilities for a land battle against the German states. ${ }^{68}$ Any intervention in support of Denmark would require the aid of other states, particularly France. ${ }^{69}$ This was highly unlikely given the new diplomatic landscape following the Crimean War and the Polish revolt, which alienated Russia from Britain and France and Britain and France from each other. French Foreign Minister Drouyn de Lhuys' made this clear in a note to the British envoy in early January 1864. Despite its sympathies for Denmark, 'France would certainly not interfere alone ... When he looked around to see who might be the possible allies of France in defence of Denmark, he found none that could be counted upon ... The question of Poland had shown that Great Britain could not be relied upon when war was in the distance ... France did not wish a collision single-handed with Germany. ${ }^{, 70}$ In addition, Palmerston's long-standing fears of Napoleon III's expansionist ambitions limited his eagerness for French assistance, which would likely leave French armies on the Rhine, posing a potential threat to Holland and Belgium. ${ }^{71}$ A. J. P. Taylor's comment about Britain in 1870 is even more appropriate for 1864: 'British policy in Europe postulated a continental ally. She had no ally; therefore could have no policy. ${ }^{, 72}$

The situation appeared to change when Prussian forces crossed from Schleswig into Jutland on 18 February, and Austrian warships moved toward Denmark. This led Palmerston and Napoleon to discuss cooperative naval actions, beginning with a proposal to send a British squadron to Copenhagen to block any Prussian attack on that city or on Zealand. Russia too was alarmed

\footnotetext{
${ }^{66}$ Evelyn Ashley, The Life and Correspondence of Henry John Temple, Viscount Palmerston, Vol. II (London: Richard Bentley \& Son, 1879), p. 434.

${ }^{67}$ HC Deb (1864-02) 173, col. 328.

${ }^{68}$ Eyck, Bismarck, p. 85; A. J. P. Taylor, The Struggle for Mastery in Europe (Oxford: Clarendon Press, 1954), p. 146. After India's Great Sepoy Rebellion in 1857-9, Britain could no longer request help from the substantial Indian army.

${ }^{69}$ Pflanze, Bismarck, p. 248.

${ }^{70}$ Mosse, European Powers, p. 163; Steefel, Schleswig-Holstein Question, pp. 166-7. Pflanze, Bismarck, p. 248, concludes that 'The Anglo-French entente was finished.'

${ }^{71}$ Steefel, Schleswig-Holstein Question, pp. 176-7; Mosse, European Powers, pp. 211-12, 221-2; Pflanze, Bismarck, p. 248; Onea, Grand Strategies, p. 91, fn. 72.

${ }^{72}$ Taylor, Struggle for Mastery, p. 206. Given the structural forces shaping Britain's isolation, it is misleading to give too much emphasis, as Goddard does, to Bismarck's rhetorical and diplomatic skill. Goddard, 'When right makes might'. Bismarck skillfully played his hand, but he was dealt a strong one. See Onea, Grand Strategies, p. 91 , fn. 72
} 
and suggested an armistice. Within days, however, the Queen's public opposition to naval action led Palmerston to put that action on hold. With fresh evidence of the lack of a sustained British commitment, Napoleon backed off and reverted to his hands-off policy. ${ }^{73}$

Bismarck followed these developments closely. When British naval action backed by France and Russia looked likely, and when even Vienna expressed concern about the move into Denmark, Bismarck backed off. He said that given Austria's hesitation, Russia's pleas for an armistice and for maintaining the integrity of the Danish Monarchy, and English threats, 'if Prussia has now to face the opposition of France as well, she will have to call a halt, for she cannot alienate the four Great Powers at once'. ${ }^{74}$ After Britain's decision to put naval action on hold and France's decision to withdraw its support, Bismarck's concerns evaporated, and he returned to a more aggressive policy. This episode demonstrates how internal opposition to the Palmerston government's policy undercut British signalling, affected Prussian policy, and undermined the likelihood of a balancing coalition against Prussian expansion. ${ }^{75}$

Fighting continued between German and Danish forces in the following months, with German forces taking most of the territory in Schleswig. In the context of continuing disagreements on policy coordination, representatives of the European powers convened in London in April 1864 to discuss a possible settlement of the Second Schleswig War. ${ }^{76}$ While Russell continued to advocate hardline policies, by mid-June Palmerston recognised that his interventionist policy was no longer viable. With the London talks breaking down, a temporary truce ending, and the expectation of the resumption of hostilities the next day, the British Cabinet, still divided but forced to make a decision, voted on 25 June for a policy of non-intervention. Reflecting its deep divisions, however, the Cabinet resolution included the qualification that any 'change in circumstances' that threatened 'the safety of Copenhagen or the existence of Denmark as an independent kingdom' would require a 'fresh decision' by the British government. ${ }^{77}$ In 27 June speeches to Parliament, Russell announced that 'we should be neutral in this war', and Palmerston said that the issues involved were not of 'great importance' to Britain. ${ }^{78}$ This marked the end of the great power crisis, but the domestic crisis in England continued. ${ }^{79}$

\section{The censure debate}

On 4 July the Conservative Benjamin Disraeli moved a vote of censure of the Liberal government in the House of Commons. He argued that 'the course pursued by Her Majesty's Government has failed to maintain their avowed policy of upholding the integrity and independence of Denmark, it has lowered the just influence of this Country in the counsels of Europe, and thereby diminished the securities for peace'. ${ }^{80}$ Disraeli's primary argument was that the policies of the Palmerston government had damaged the reputation of Britain throughout Europe. As Richard Cobden declared, 'Our Foreign Office has lost its credit with foreign countries. ${ }^{81}$

Disraeli linked the failures of the Palmerston government (and the Liberal party) on the Danish question to its earlier blunders in Poland, where its retreat from its promised support for Polish rebels had alienated France, depriving Britain of the vital ally it would need a year

\footnotetext{
${ }^{73}$ Steefel, Schleswig-Holstein Question, pp. 176-7; Mosse, European Powers, pp. 179-80; Morris, 'The Danish-German war', p. 134 .

${ }^{74}$ Mosse, European Powers, p. 181

${ }^{75}$ As we noted earlier, this pattern fits models of domestic political opposition and war. Schultz, Democracy and Coercive Diplomacy. Unlike models of partisan opposition, however, the opposition to Palmerston was driven by policy disagreements within his own Liberal party in Parliament.

${ }^{76}$ Steefel, Schleswig-Holstein Question, pp. 225-6; Eyck, Bismarck, p. 91.

${ }^{77}$ Sandiford, Great Britain and the Schleswig-Holstein Question, pp. 111-12.

${ }^{78} \mathrm{HC}$ Deb (1864-06) 176, cols 337-355.

${ }^{79}$ Denmark's government resigned and a new government successfully requested an armistice that began 20 July. The Treaty of Vienna formally ended the war on 30 October, dividing the duchies into areas of Austrian and Prussian control.

${ }^{80}$ HC Deb (1864-07) 176, col. 1220.

${ }^{81}$ HC Deb (1864-07) 176, col. 184.
} 
later. He highlighted the fundamental problems with a policy of making promises to Denmark that it could not deliver and threats against the Germans that it could not back up, and continuing this policy even after it became clear that France would stand aside. ${ }^{82}$ Disraeli's argument fits audience cost theory's emphasis on the inconsistency mechanism based on international reputational costs, but it also illustrates the close link between inconsistency and incompetence. ${ }^{83}$ Lord Stanley echoed the incompetency theme when he declared that 'you have blundered these foreign negotiations from beginning to end'. He summarised the results of recent liberal policies as 'France alienated, Germany insulted, Denmark abandoned, Poland encouraged and left to perish. $^{84}$

Some Liberals and other members who had come out against the use of force voiced concerns about the inconsistency in Palmerston's policy. ${ }^{85}$ Bernal Osborne argued that despite the peaceful outcome, the means through which it was obtained were troubling, and that 'the failure of the Ministry to some extent involves the honour of [the] country'. ${ }^{86}$ Most Liberals, however, did not concede that Britain's prestige had suffered, weakening their case given the evidence. ${ }^{87}$ Some Liberals argued on more substantive grounds against their leaders' interventionist policies. Cobden, leader of the free-trading Manchester liberals, emphasised the negative economic consequences of war. Gladstone and other Liberal MPs countered that Conservatives had not offered a policy position of their own at any time throughout the conflict, a theme widely repeated in the British press but rejected by Stanley, who argued that formulating clear policy was not the responsibility of the opposition. The Liberal Horsman echoed Gladstone's argument and argued that the failure was a national one, not a Liberal one, because the Palmerston government had followed the sympathies of the pro-Danish public and Parliament. ${ }^{88}$ On 8 July the House of Commons voted 313 to 295 against censure. ${ }^{89}$ Despite their criticisms of the government's policy inconsistency, anti-interventionist Liberals voted against Parliamentary censure. As Sandiford argues, the vote was 'a simple question of party-politics'. 90

The same day, Lord Malmesbury introduced a motion of censure in the House of Lords, where members generally repeated the same arguments made in the House of Commons. The government had made 'too many promises to Denmark and too many threats to Germany', and its policies were riddled with inconsistency. ${ }^{91}$ The inconsistency theme was central to Lord Robert Cecil's declaration that the government's policies were 'founded upon no definite principle ... oscillating, vague, and fluctuating in its course..$^{92}$ In a statement that perfectly captures the leading explanation for domestic punishment in audience costs theory, Cecil also declared that 'If we did not intend to carry out by arms our threats and measures, we must abstain from the luxury of indulging in them. That is the only policy for the future which I believe is involved in the censure of the government for the past. ${ }^{93}$

\footnotetext{
${ }^{82}$ Sandiford, Great Britain and the Schleswig-Holstein Question, p. 132.

${ }^{83}$ On the impact of competency on inconsistency costs, see Ayala Yarkoney Sorek, Kathryn Haglin, and Nehemia Geva, 'In capable hands: An experimental study of the effects of competence and consistency on leadership approval', Political Behavior, 40:3 (2018), pp. 659-79.

${ }^{84}$ Sandiford, Great Britain and the Schleswig-Holstein Question, pp. 132-3.

${ }^{85}$ This deviates from arguments that doves do not criticize leaders for failing to follow through on threats. See Snyder and Borghard, 'The cost of empty threats', pp. 442, 445; Kertzer and Brutger, 'Decomposing audience costs'.

${ }^{86} \mathrm{HC}$ Deb (1864-07) 176, cols 1200-1201.

${ }^{87}$ Taylor, after quoting the French ambassador's statement that the British 'are now retreating vigorously', argues that the Cabinet's non-interventionist resolution of 25 June 'has usually been regarded as a catastrophic blow to British prestige'. Taylor, Struggle for Mastery, p. 154.

${ }^{88}$ Sandiford, Great Britain and the Schleswig-Holstein Question, pp. 131-8.

${ }^{89} \mathrm{HC}$ Deb (1864-07) 176, cols 1198-1305.

${ }^{90}$ Sandiford, Great Britain and the Schleswig-Holstein Question, p. 136.

${ }^{91}$ Ibid.

${ }^{92}$ Great Britain, House of Lords, Debates (1864-07) 176, col. 843 (hereafter HL Deb).

${ }^{93}$ Mosse, European Powers, p. 208.
} 
Reputational concerns were paramount. As Lord Derby stated just after the German forces invaded Schleswig, 'This country is now in such a position that its menaces are disregarded, its magniloquent language is ridiculed, and its remonstrances are treated with contemptuous indifference by the small as well as the great Powers of the Continent. ${ }^{94}$ In defence, the government blamed the outcome on the immorality of the European great powers. Conservatives countered that the Palmerston government had contributed to its diplomatic isolation through its misguided policies in Poland in 1863, and that it continued its swaggering and bombastic rhetoric well after it was clear it would not be getting the external support without which it could not act. $^{95}$

The 8 July vote of censure passed with a vote of 177 to $168 .^{96}$ This was a thinner margin than many expected. Russell said that they had done 'better than could be expected in both Houses'. Palmerston agreed. ${ }^{97}$ Still, the process had been humiliating, particularly because Liberals as well as Conservatives had condemned the government.

\section{The public and media response}

The public and the media were more supportive of Palmerston after the censure vote, though both audiences remained mixed in their attitudes towards war and the substance of British policy regarding Schleswig-Holstein. ${ }^{98}$ Most media outlets denounced the decision in the House of Lords, with only the most conservative media criticising Palmerston after the censure. ${ }^{99}$ Palmerston's influence over several media outlets and his unique skill for cultivating favourable opinion helps to explain his favourable media coverage. ${ }^{100}$ Palmerston was successful in developing formal and informal connections to most of the British newspapers, and most portrayed him in a good light to the public. Cartoonists were particularly influential in this respect, often drawing Palmerston with vigour and wisdom while portraying his opponents as being shrivelled, old, and inept. In his later years he was admired for his vitality and regarded as a father figure. ${ }^{101}$

Palmerston's political skills in managing relationships within the House of Commons and the Cabinet contributed to popularity within Parliament. ${ }^{102}$ The ultimate basis of Palmerston's popularity in the media and in Parliament, however, was his unprecedented popularity among the British public. Palmerston remained 'impossibly popular', ${ }^{103}$ an 'unequalled and marvelous influence'. ${ }^{104} \mathrm{His}$ popularity extended across all classes of society, including the working classes. ${ }^{105}$ This popularity was initially based on his aggressive and highly successful foreign policy, but it outlasted support for that policy.

This popularity remained high after the censure vote. Russell wrote to Palmerston that his popularity is 'a plant of hardy growth and deep roots, as the real embarrassments of the Danish have not shaken it'. ${ }^{106}$ Palmerston remained a considerable asset to the Liberal party, which won 60 per cent of the vote in the July 1865 election, ${ }^{107}$ with Palmerston retaining

\footnotetext{
${ }^{94}$ HL Deb (1864-02) 173, col. 29.

${ }^{95}$ Sandiford, Great Britain and the Schleswig-Holstein Question, pp. 137-8.

${ }^{96}$ HL Deb (1864-07) 176, cols 1076-1193.

${ }^{97}$ Steefel, Schleswig-Holstein Question, p. 249; Mosse, European Powers, 209.

${ }^{98}$ Sandiford, Great Britain and the Schleswig-Holstein Question, p. 96.

${ }^{99}$ Sandiford, Great Britain and the Schleswig-Holstein Question, pp. 138-42; Fenton, Palmerston and the Times, p. 43.

${ }^{100}$ Fenton, Palmerston and the Times, pp. 43-6, 158-61.

${ }^{101}$ Ridley, Lord Palmerston, pp. 522-30.

${ }^{102}$ Ibid.

${ }^{103}$ Brown, Palmerston, p. 462.

${ }^{104}$ Walter Bagehot, cited in Herbert C. F. Bell, Lord Palmerston, Vol. II (Hamden: Archon Books, 1966), p. 416.

${ }^{105}$ Noting the importance of Lady Palmerston's parties in cultivating her husband's popularity in political and social circles is Ridley, Lord Palmerston, p. 522.

${ }^{106}$ Ashley, Viscount Palmerston, p. 437.

${ }^{107}$ Colin Rallings and Michael Thrasher, British Electoral Facts, 1832-1999 (Burlington: Ashgate Publishing Company, 2000), p. 9.
} 
his position as prime minister. Historians attribute the outcome to Palmerston's popularity. ${ }^{108}$ Three months later The Times obituary said that 'There never was a statesman who more truly represented England than Lord Palmerston., ${ }^{109}$

The continued high levels of public support for Palmerston in the aftermath of the Schleswig-Holstein crisis and the censure debate run contrary to the predictions of audience costs theory. The primary explanation lies in Palmerston's prior popularity among the public, a variable that audience cost theorists have largely neglected. This conclusion is consistent with a recent argument, confirmed by an experimental study, that audience costs theorists should give more attention to a leader's 'general approval' than their 'situational approval' in response to particular actions and events. ${ }^{110}$

\section{Impact of the crisis and censure debate on British foreign policy}

Audience costs theory does not address the issue of whether leaders who make a threat, fail to follow through, and suffer domestic punishment learn from their experience and subsequently adjust their policies. ${ }^{111}$ The British foreign policy response to the Schleswig-Holstein crisis suggests that leaders can learn about audience costs and domestic constraints on foreign policy more generally. Given Palmerston's death in October 1865, we focus on Russell, Palmerston's Foreign Secretary who succeeded him as prime minister. Russell's hardline beliefs, statements, and policy preferences prior to the censure debate provide a useful baseline against which to compare his subsequent statements and actions. We argue that Russell and the Cabinet learned from their experience in the Schleswig-Holstein affair and their censure by Parliament. In Paul M. Kennedy's words, 'the lesson which subsequent ministries took from this affair came very close to the Bright-Cobdenite view that in [the] future a belligerent policy could only be initiated when the vast majority of the country support the government'. Given policy divisions within Britain, 'such a precondition was sufficient to rule out the resort to war in all but the most pressing circumstances'. ${ }^{112}$ This lesson had a profound impact on the subsequent conduct of British foreign policy. This is an enormously important historical question because of the consequences of Britain's failure to balance against Prussia in the wars of German unification of 1866 and 1870, and, some say, of its failure to issue a timely warning against Germany in $1914 .{ }^{113}$

British leaders and elites in the mid-1860s spoke about the fundamental change in British policy after the Schleswig-Holstein affair. In January 1865 Radical Liberal John Bright declared that the political defeat of Palmerston marked the fatal end of the 'foul idol' of the balance of power as an abstract doctrine in British foreign policy. ${ }^{114}$ Richard Cobden agreed, and said that 'We have achieved a revolution in our foreign policy. ${ }^{, 15}$ In May 1866 Foreign Secretary Clarendon informed his ambassador to Paris that Britain was 'willing to do anything for the maintenance

\footnotetext{
${ }^{108}$ Bell, Lord Palmerston, pp. 414-16; W. Barrington Pemberton, Lord Palmerston (London: Batchworth Press, 1954), p. 579.

${ }^{109}$ Fenton, Palmerston and the Times, p. 160.

${ }^{110}$ Sarah E. Croco, Michael J. Hanmer, and Jared A. McDonald, 'At what cost? Reexamining audience costs in realistic settings', Journal of Politics, 83:1 (2021), pp. 8-22.

${ }^{111}$ This presumably results from the theory's assumption that leaders understand audience costs and anticipate their effects.

${ }^{112}$ Kennedy, Rise of the Anglo-German Antagonism, p. 12.

${ }^{113}$ Many argue that Britain's failure to issue an explicit deterrence threat against Germany in the 1914 July Crisis was an important cause of the First World War. Fritz Fischer, Germany's Aims in the First World War (New York: W. W. Norton, 1967 [orig. pub. 1961]), ch. 2; Jack S. Levy, 'Preferences, constraints, and choices in July 1914', International Security, 15:3 (1990/91), pp. 151-86. On the influence of the First World War experience on the historiography of the Schleswig-Holstein crisis, see T. G. Otte, The Foreign Office Mind: The Making of British Foreign Policy, 1865-1914 (Cambridge: Cambridge University Press, 2011), p. 23.

${ }^{114}$ Michael Brock and Eleanor Brock, Margot Asquith's Great War Diary, 1914-1916: The View from Downing Street (Oxford: Oxford University Press, 2014), p. lxxviii.

${ }^{115}$ Quoted in Ramsay, Idealism and Foreign Policy, p. 132.
} 
of peace ... except committing ourselves to a policy of action that ... would not be sanctioned by public opinion at home'. ${ }^{116}$ In response to the Queen's balance-of-power-driven insistence on acting in conjunction with France to block Prussian expansion in 1866, reversing her position in the earlier crisis, Clarendon wrote that even with the support of France, Britain could not use 'the language of menace which might entail the necessity of action'. ${ }^{117}$ In July 1866 the future Marquis of Salisbury wrote

The policy that was pursued in 1864 has undoubtedly had the effect of severing [England] in a great measure from the course of continental politics and the declared principles of nonintervention ... have necessarily diminished her influence in the decision of Continental questions. The general feeling in this country is in favour of abandoning the position which England held for so many years in the councils of Europe. ${ }^{118}$

The question is whether this profound shift in British policy was the causal result of learning, defined as belief change, or something else. A brief analysis suggests support for the learning hypothesis. We find that Russell learned several lessons from the Schleswig-Holstein crisis and from the censure debate in particular. He learned that the prime minister could not persuade the Cabinet, Queen, and Parliament to support a policy of deterrence unless the threat to British interest was unambiguous and immediate and unless Britain had great power support. $\mathrm{He}$ also learned that Britain was diplomatically isolated, that Bismarck was not easily deterred, and that making an external threat and failing to follow through generated domestic costs.

There is little doubt that Russell's beliefs changed significantly. Our earlier discussion emphasised Russell's strongly held ideas about the importance of limiting Prussian expansion, the utility of deterrent threats, and confidence in Britain's ability to secure the support of allies. He pushed for policies based on those beliefs more consistently than did Palmerston, and for a longer period of time. By mid-June 1864, as the London Conference to settle the Danish dispute approached an end, it was clear that Palmerston was 'much less warlike' than Russell. ${ }^{119}$ Palmerston had come around to the Queen's position by their 21 June meeting. Russell, however, continued to maintain a hardline policy and uncompromising rhetoric until the Cabinet decided on 25 June, against his protests, to withdraw from the Dano-German dispute. As prime minister two years later, however, Russell was far more cautious. He declared that 'if you enter a war merely for the sake of preserving the general balance of power in Europe, without your interests or honour being involved, you ought to see whether you are not likely to produce much more evil than you are likely to remedy'. ${ }^{120}$

It is fairly easy to rule out two possible alternative explanations for the sudden change in Russell's views and British policy. One, with two variations, emphasises structural adjustment to a changing international environment. In terms of a change in the external threat environment, Prussian expansion was clearly more of a threat to the European balance of power and British interests in particular 1866 and 1870 than in 1863-4, which explains Queen Victoria's shift to an interventionist policy preference in 1866. Russell, given his prior beliefs, should have been even more willing to organize a balancing coalition. If the structural change refers to declining resources, ${ }^{121}$ the gradual nature of that trend cannot alone explain the abruptness of British policy change in the two years after the second Schleswig-Holstein crisis. Turning to domestic explanations, we can rule out the possibility that new leaders come to power with long-standing but

\footnotetext{
${ }^{116}$ Richard Millman, British Foreign Policy and the Coming of the Franco-Prussian War (Oxford: Clarendon Press, 1965), pp. $20-1$.

${ }^{117}$ Mosse, European Powers, p. 230.

${ }^{118}$ Ibid., p. 209.

${ }^{119}$ Sandiford, Great Britain and the Schleswig-Holstein Question, pp. 110-11.

${ }^{120} \mathrm{HC}$ Deb (1866-05) 183, col. 576.

${ }^{121}$ Paul K. MacDonald and Joseph M. Parent, Twilight of the Titans: Great Power Decline and Retrenchment (Ithaca, NY: Cornell University Press, 2018), ch. 4.
} 
unchanged beliefs but with a new position of power from which they are able to implement their policy preferences. This would be political turnover rather than learning, but it certainly does not apply to Russell, given his earlier hardline views. ${ }^{122}$

Historians generally agree that the mid-1860s mark a fundamental change in British grand strategy, and many trace the change to the humiliation of the Schleswig-Holstein crisis. William Mosse, describes this period as a 'turning-point in British diplomacy', and argues that 'the Whig policy of 'intervention' of which [Palmerston and Russell] had been the chief exponents was thoroughly discredited with public and Parliament alike'. ${ }^{123}$ Kennedy attributes the radical change to the new policy of non-interference to the fact that 'the consciousness of both parties [Liberals and Conservatives] was ridden with the memory of the Schleswig-Holstein humiliation'. ${ }^{124}$ Prest argues that the debate over Palmerston's Schleswig-Holstein policy was 'decisive for British foreign policy in the nineteenth century'. ${ }^{125}$ Richard Millman observes that Queen Victoria, Russell, and Clarendon had all agreed 'that the disgrace of 1864, the opprobrium of promising more than was delivered, should not be repeated', and that British aloofness from the 1866 crisis was a consequence of the Parliamentary censure. ${ }^{126}$

\section{Theoretical implications}

The Schleswig-Holstein crisis offers a rich but complex perspective on audience costs theory. Behaviour in the crisis is consistent with some of the theory's assumptions and propositions but inconsistent with many others. British behaviour also suggests an interesting variant on Schultz's model of political oppositions and signalling. ${ }^{127}$

Contrary to audience costs theory's prediction that the anticipation of domestic punishment for making threats but not following through discourages leaders from bluffing, Palmerston's threat in the House of Commons against German intervention in Holstein and Schleswig was a bluff. The prime minister was confident that the deterrent threat would work, but he never seriously considered whether Britain had the military capabilities or allied support to implement the threat. This violates audience costs theory's key assumption that leaders factor the balance of relative capabilities and interests into their decisions to initiate a crisis, so that observable capabilities and interests do not have an impact on intra-crisis bargaining. ${ }^{128}$ Britain's inadequate capabilities and lack of allied support were in fact quite observable. They constituted the primary motivation for the Queen and many in the British Cabinet and Parliament to question the wisdom of the government's coercive policies, which reduced the government's external bargaining leverage. In addition, Bismarck's understanding of Britain's weakness was the basis of his calculations that Palmerston would not resist Prussian action in Denmark. Thus contrary to the audience costs assumption that the balance of capabilities influences the decision to enter a crisis but not bargaining during a crisis, the reality for Britain in the Schleswig-Holstein crisis was the reverse. Assessments of relative capabilities and resolve influenced bargaining within the crisis but not the decision to enter the crisis.

In addition to encouraging parliamentary opposition to the government's policies, Queen Victoria also corresponded directly with foreign monarchs and envoys. She assured both adversaries and allies of Britain's peaceful intentions, and in doing so undermined the credibility of Palmerston's signals. The domestic struggle in Britain also left foreign observers to question whether the British government's negotiations over the terms of a possible settlement were

\footnotetext{
${ }^{122}$ There were no fundamental changes in the structure and personnel of Britain's diplomatic elite that might explain Britain's policy changes. Otte, Foreign Office Mind, p. 24.

${ }^{123}$ Mosse, The European Powers, p. 209.

${ }^{124}$ Kennedy, The Rise of the Anglo-German Antagonism, 1860-1914, pp. 16-20.

${ }^{125}$ John Prest, Lord John Russell (Columbia: University of South Carolina Press, 1972), p. 398.

${ }^{126}$ Millman, British Foreign Policy and the Coming of the Franco-Prussian War, pp. 7-8.

${ }^{127}$ Schultz, Democracy and Coercive Diplomacy.

${ }^{128}$ Fearon, 'Domestic political audiences', p. 578.
} 
genuine or directed at a domestic audience. As Cobden argued in the House of Commons, foreign leaders 'mistrust[ed]' British government and believed that the 'Foreign Minister is often playing a game with them ... merely to suit his policy and his prospects in this House. ${ }^{129}$

These efforts to prevent Palmerston from implementing his threat originated long before Prussia and Austria defied the threat with their military intervention in the duchies and before Palmerston chose not to respond. These efforts imposed costs on the government, but these costs were not audience costs. They more closely fit Schultz's model of the impact of political oppositions and crisis bargaining, but with a major difference. ${ }^{130}$ In contrast to Schultz's emphasis on the behaviour of an opposition political party motivated by partisan interests, the British opposition in Schleswig-Holstein crisis came from within the governing Liberal party, and it was motivated by policy disagreements. Schultz's model explains the consequences of political opposition for crisis bargaining in 1863-4 crisis, but not the identity of the opposition or its motivations.

With the censure debate in the House of Commons and the vote for censure in the House of Lords, the Palmerston government did suffer audience costs, but the nature and magnitude of those costs are hard to specify. There is no doubt that the parliamentary debates and censure were humiliating for Palmerston and his government. They also contributed to a fundamental change in British foreign policy, away from the interventionist orientation that defined and symbolised Palmerston's ministership. It is reasonable to treat this policy shift as a cost for Palmerston, but this shift was more the result of policy opposition that contributed to the German defiance of the government's threat (which are not technically audience costs) than to the government's failure to implement the threat after that defiance. More problematic for audience costs theory, Palmerston remained popular. He was re-elected within a year, and his popularity contributed to electoral gains for his Liberal party.

If we go inside the censure debates and look at the rhetoric employed, however, we find that many of the specific arguments advanced in support of censure centred on the inconsistency of the government's policies, particularly the inconsistency between making a threat and then not following through. Moreover, arguments about the costs of inconsistency emphasised the reputational costs to the state, among both adversaries and allies. All of this conforms with standard audience costs arguments. The fact that many Liberals who supported the government criticised its inconsistent policies suggests that partisanship was not the driving force behind the criticisms of Palmerston, although party politics clearly drove the vote of most Liberals against censure in the House of Commons.

The Parliamentary debates bear on the argument, advanced by some, that perceptions of incompetency, not just inconsistency, drive punishment. ${ }^{131}$ Many speakers argued that policy inconsistency, along with Palmerston's failure to secure diplomatic support before or after making threats that Britain alone lacked the capability to enforce, was an indicator of the government's incompetence. Some speakers linked the fatal British isolation to the government's mismanagement of (and inconsistency in) its response to the 1863 Polish crisis, which alienated France from Britain. This line of argument suggests a need to rethink the common analytic distinction between inconsistency and incompetence as alternative mechanisms driving audience costs. Policy inconsistency is one indicator of incompetence, but one can be incompetent without being inconsistent. One can be consistently incompetent.

We have also raised the question of whether leaders learn from their experiences of audience costs. Are leaders who suffer audience costs less likely to make future threats, and more likely to insist on a higher level of confidence in their relative military strength and support from allies and domestic publics before they make those threats? Do adversaries anticipate that reaction and become both more emboldened in their future actions and more cautious in responding to threats made against them? Given the difficulty of separating audience costs, conceived in most of the literature as public

\footnotetext{
${ }^{129}$ HC Deb (1864-07) 176, col. 841.

${ }^{130}$ Schultz, Democracy and Coercive Diplomacy.

${ }^{131}$ Smith, 'International crisis'; Gelpi and Grieco, 'Competency costs'; Nomikos and Sambanis, 'What is the mechanism?'
} 
punishment for making a threat and not following through, from costs imposed by opposition to government policy before the adversary's defiance of the threat (and contributing to that defiance), we broaden our question about learning to include both sets of costs.

Learning is often difficult to establish empirically, in part because evidence of policy change is not necessarily evidence of learning. ${ }^{132}$ Our analysis is complicated by the fact that Palmerston died before policy changes were fully implemented. But the well-established prior beliefs of the new prime minister, the striking changes in Russell's beliefs and policies, statements from other key British officials, shared interpretations among historians, and the absence of other plausible explanations for the sea change in British policy all support the learning hypothesis. This is another fruitful area for further research.

The simplifying assumptions of standard audience costs theory have facilitated the construction of powerful formal models and experimental protocols that have sustained an extraordinarily successful research program for the last quarter-century. Although the 1863-4 Schleswig-Holstein crisis fits some assumptions and predictions of standard models of audience costs theory, it deviates from others. Palmerston did not factor in the balance of capabilities or of resolve into his decision to initiate his threat; he made no effort to secure external allies or public support; and he was unaware of the implications of his public threat for crisis bargaining. Whereas standard audience costs models move directly from a leader's threat to the adversary response, without anything of any significance intervening, in the Schleswig-Holstein crisis the intervening behaviour was critical. Members of Parliament, encouraged by the Queen, tried to soften the government's threats, and the Queen communicated directly with the targets to reassure them of Britain's benign intentions. Bismarck, understanding these internal divisions and resulting mixed signals, discounted the British's government's attempts to reinforce its threats. He manoeuvred carefully to prevent a broader coalition from forming against him and to accentuate political divisions within Britain. Thus, most of the action with respect to signalling occurred between the initial threat and the target's defiant response. Audience costs theory misses the broader political nature of signalling. The Schleswig-Holstein crisis may be more complicated than most, but many of these patterns are undoubtedly present in other cases, though admittedly the specific role of the Queen may not be generalisable. Some of these patterns can be modelled and incorporated into experimental designs, while some are more usefully explored through process tracing in historical case studies. Neither methodology alone can capture the complex processes of signalling in crisis bargaining. We need to incorporate audience costs into a broader theory of the domestic politics of signalling.

Acknowledgements. We thank Michael McKoy, William Mulligan, Tudor Onea, and several anonymous reviewers for their insightful and constructive comments.

Jayme R. Schlesinger is a doctoral candidate in the Political Science department at Rutgers University. Her research focuses primarily on decision-making and effectiveness in terrorism and counterterrorism. Her dissertation studies how terrorist attacks might vary in their effectiveness to help terrorist achieve their long-term objectives based on the characteristics of violence they employ. Author's email: jayme.schlesinger@rutgers.edu

Jack S. Levy is Board of Governors' Professor of Political Science at Rutgers University and Senior Research Scholar at the Saltzman Institute of War and Peace Studies at Columbia University. He is past president of the International Studies Association and of the Peace Science Society (International). His recent books include The Outbreak of the First World War: Structure, Politics, and Decision-Making (2014, co-edited with John A. Vasquez); The Oxford Handbook of Political Psychology (2 ${ }^{\text {nd }}$ edn, 2013, co-edited with Leonie Huddy and David O. Sears), and Causes of War (2010, with William R. Thompson). Author's email: jacklevy@rutgers.edu

${ }^{132}$ Levy, 'Learning and foreign policy', pp. 289-91.

Cite this article: Schlesinger, J. R., Levy, J. S. 2021. Politics, audience costs, and signalling: Britain and the 1863-4 SchleswigHolstein crisis. European Journal of International Security 6, 338-357. https://doi.org/10.1017/eis.2021.7 